\title{
Universiteit
}

Leiden

The Netherlands

\section{Modulation of spectral properties and pump activity of proteorhodopsins by retinal analogues}

Ganapathy, S.; Becheau, O.; Venselaar, H.; Frolich, S.; Steen, J.B. van der; Chen, Q.; ... ; Grip, W.J. de

\section{Citation}

Ganapathy, S., Becheau, O., Venselaar, H., Frolich, S., Steen, J. B. van der, Chen, Q., ... Grip, W. J. de. (2015). Modulation of spectral properties and pump activity of proteorhodopsins by retinal analogues. Biochemical Journal, 467(2), 333-343. doi:10.1042/BJ20141210

Version:

Publisher's Version

License:

Licensed under Article 25fa Copyright Act/Law (Amendment Taverne)

Downloaded from: https://hdl.handle.net/1887/3198447

Note: To cite this publication please use the final published version (if applicable). 


\title{
Modulation of spectral properties and pump activity of proteorhodopsins by retinal analogues
}

\author{
Srividya Ganapathy ${ }^{*} \dagger^{1}$, Odette Bécheau*, Hanka Venselaarł, Siebren Frölich ${ }^{\star}$, Jeroen B. van der Steen $\S$, Que Chen $\S$, \\ Sarah Radwan*, Johan Lugtenburg*, Klaas J. Hellingwerf§, Huub J. M. de Groot* and Willem J. de Grip*1 \\ *Department of Biophysical Organic Chemistry, Leiden Institute of Chemistry, Gorlaeus Laboratories, Leiden University, P.0. Box 9502, 2300 RA Leiden, The Netherlands \\ $\dagger$ BioSolar Cells, P.0. Box 98, 6700 AB Wageningen, The Netherlands \\ $\$$ Centre for Molecular and Biomolecular Informatics, Radboud University Medical Center, P.0. Box 9101, 6500 HB Nijmegen, The Netherlands \\ $\S$ Swammerdam Institute for Life Sciences, University of Amsterdam, P.0. Box 94215, 1090 GE Amsterdam, The Netherlands
}

Proteorhodopsins are heptahelical membrane proteins which function as light-driven proton pumps. They use all-trans-retinal A1 as a ligand and chromophore and absorb visible light (520$540 \mathrm{~nm}$ ). In the present paper, we describe modulation of the absorbance band of the proteorhodopsin from Monterey Bay SAR 86 gammaproteobacteria (PR), its red-shifted double mutant PR-D212N/F234S (PR-DNFS) and Gloeobacter rhodopsin (GR). This was approached using three analogues of all-transretinal A1, which differ in their electronic and conformational properties: all-trans-6,7-s-trans-locked retinal A1, all-transphenyl-retinal A1 and all-trans-retinal A2. We further probed the effect of these retinal analogues on the proton pump activity of the proteorhodopsins. Our results indicate that, whereas the constraints of the retinal-binding pocket differ for the proteorhodopsins, at least two of the retinal analogues are capable of shifting the absorbance bands of the pigments either bathochromically or hypsochromically, while maintaining their proton pump activity. Furthermore, the shifts implemented by the analogues add up to the shift induced by the double mutation in PR-DNFS. This type of chromophore substitution may present attractive applications in the field of optogenetics, towards increasing the flexibility of optogenetic tools or for membrane potential probes.

Key words: chromophore, microbial rhodopsins, retinal analogues, spectral sensitivity.

\section{INTRODUCTION}

Microbial rhodopsins (also called type-I rhodopsins) are a large family of light-sensitive heptahelical transmembrane proteins found in archaea (e.g. bacteriorhodopsin, sensory rhodopsin II), bacteria (e.g. proteorhodopsins, Anabaena sensory rhodopsin) and eukaryotes (e.g. algal and fungal rhodopsins) [1-3]. These proteins mediate a variety of functions in their hosts, including phototactic signalling and active transport of ions. The archaeal proton pump bacteriorhodopsin (BR) is the first identified of these rhodopsins and the best studied over the last four decades [4-6]. The first proteorhodopsin was discovered in gammaproteobacteria of the SAR 86 group, from Monterey Bay in California, U.S.A. (PR) [7]. PR contains the transmembrane motif with seven $\alpha$ helices and the chromophoric ligand all-trans-retinal A1, common to all rhodopsins, and shares approximately $20 \%$ sequence identity with BR [7].

Many different variants of PR have been found since, widely distributed in marine, freshwater and terrestrial biotopes [8]. PR could successfully be heterologously expressed in Escherichia coli [9-14] and was shown to function as a light-driven proton pump after incubation with retinal [7]. The phototrophic potential of PR can be exploited to drive physiological activities in a heterologous environment such as flagellar motility or ATP synthesis in $E$. coli $[10,11]$. In native organisms, PR has been shown to enhance survival or growth rate under energy-limiting conditions $[15,16]$. This potential and their wide distribution suggests that PRs are a key player in the phototrophic energy balance of the biosphere.

PR covalently binds all-trans-retinal A1 (Figure 1) through a protonated Schiff base with Lys $^{231}$ of helix G, yielding a new absorbance band peaking at $\sim 525 \mathrm{~nm}[7,17,18]$. Absorption of a single photon leads to the isomerization of the all-trans chromophore to the 13-cis configuration, which in turn induces a sequence of specific structural changes in the protein moiety (opsin) [7,19]. As a consequence, a proton is transferred from the cytoplasmic to the extracellular side of the membrane, creating a protonmotive force.

More recently, a type I rhodopsin (GR) was discovered in the genome of the cyanobacterium Gloeobacter violaceus $\mathrm{PCC}$ 7421 [20]. Heterologous expression in E. coli and reconstitution with retinal generated an absorbance band peaking at $\sim 540 \mathrm{~nm}$ [21]. GR also exhibits proton pump activity [21,22]. The photocycles of PR and GR are similar to that of BR [19], but their absorbance bands are strongly blue-shifted from BR ( $\sim 570 \mathrm{~nm})$.

The length of the $\pi$-conjugated polyene chain in the chromophore, along with its interactions with protein residues lining the binding pocket, in combination with the distance between the protonated Schiff base and the counterion charge will determine the energy gap between the ground and excited state of the retinal chromophore. These tuning processes in concert shape and position the absorbance band of the proteorhodopsins.

Abbreviations: BR, bacteriorhodopsin; CCCP, carbonyl cyanide m-chlorophenylhydrazone; ChR, channel rhodopsin; DDM, 1-n-dodecyl- $\beta$-Dmaltopyranoside; GR, Gloeobacter rhodopsin; Ni-NTA, Ni ${ }^{2+}$-nitrilotriacetate; PR, proteorhodopsin from Monterey Bay SAR 86 gammaproteobacteria; PR-DNFS, PR-D212N/F234S; SRII, sensory rhodopsin II; WT, wild-type; XR, xanthorhodopsin.

1 Correspondence may be addressed to either of these authors (email s.ganapathy@chem.leidenuniv.nl or w.j.de.grip@umail.leidenuniv.nl). 
<smiles>CC1=C(/C=C/C(C)=C/C=C/C(C)=C/C=O)C(C)(C)CCC1</smiles>

(A)<smiles>CC1=C2C=C(/C(C)=C/C=C/C(C)=C/C=O)CCC2(C)CCC1</smiles>

(C)<smiles>CC1=C(/C=C/C(C)=C/C=C/C(C)=C/C=O)C(C)(C)CC=C1</smiles>

(B)<smiles>CC(/C=C/C=C(C)/C=C/c1ccccc1)=C\C=O</smiles>

(D)

Figure 1 Chemical structures of the all-trans isomers of retinal A1 and the analogues used in the present study

(A) Retinal A1, the native ligand of microbial rhodopsins. (B) Retinal A2, which contains an additional double bond between C3 and C4. (C) All-E-locked retinal A1, locked in a 6-s-trans configuration. (D) Phenyl-retinal A1, containing an aromatized ring lacking the methyl groups.

The trans $\rightarrow$ cis photo-isomerization in the chromophore induces proton transfer from the Schiff base to the proton acceptor $\left(\mathrm{Asp}^{97}\right.$ in $\mathrm{PR}, \mathrm{Asp}^{121}$ in GR), thereby triggering a complex mechanism involving proton release at the extracellular surface, proton uptake from the cytoplasmic surface and thermal reisomerization of the chromophore. The latter processes largely determine proton pump activity and depend not only on the protein machinery, but also on the conformational properties of the ligand. For instance, the electronic distribution in the chromophore will affect the $\mathrm{p} K_{\mathrm{a}}$ of the Schiff base [2325], and its structure and fit into the binding pocket will determine the distance to the counterion and to the protonaccepting residue and may have long-range effects on the protein structure.

In the present study, we investigate the effects of three retinal analogues, which differ in electronic and conformational properties, on functional properties of wild-type (WT) PR and GR, expressed in E. coli. We further include the red-shifted double mutant PR-D212N/F234S (PR-DNFS) [13] to test whether any spectral shift introduced by an analogue is additive to the mutation-induced shift. The three all-trans analogues of the native retinal A1 are retinal A2, phenyl-retinal A1 and 6-s-trans locked retinal A1 (Figure 1). Retinal A2 has the same structural make-up as retinal A1, but contains an elongated $\pi$-conjugated polyene chain. This analogue has been shown to red-shift the absorbance band of archaeal rhodopsins [26-29] and xanthorhodopsin (XR) [30]. We anticipated that this analogue would have a similar effect on the proteorhodopsins. Phenyl-retinal A1 contains an even more complex conjugated system, but lacks the methyl groups in the ring element. This analogue blue-shifts the absorbance band of BR [31,32] and probably of XR as well [30,33]. In 6-strans-locked retinal A1, the C6-C7 bond is locked in an s-trans configuration. The use of this analogue corroborated evidence that the chromophore in BR and XR contains a 6-s-trans configuration [34].

Our results show that the binding pocket constraints differ for PR and GR, as well as that retinal analogues can significantly modulate the spectral properties of proteorhodopsins with at least partial preservation of proton pump activity. Furthermore, we show that in PR-DNFS, the analogueinduced spectral shifts are additive to the mutation-induced shift.

\section{MATERIALS AND METHODS}

\section{Materials}

Escherichia coli strain UT5600 and the pKJ900 plasmids encoding PR or GR with a C-terminal $\mathrm{His}_{6}$ tag were a gift from Dr K. Jung (University of Seoul, Seoul, South Korea) [13]. UT5600 was used to express the recombinant proteins. All-trans-retinal A1 was obtained from Sigma-Aldrich. The alltrans analogues retinal A2 and all-E-6-s-trans locked retinal A1 were prepared as described previously [34,35]. All-transphenyl-retinal A1 was synthesized in analogy to retinal A1 and A2, but starting from benzaldehyde, and the structure was confirmed by ${ }^{1} \mathrm{H}-\mathrm{NMR}$ [36]. Sources of special chemicals include: IPTG from Promega, $1-n$-dodecyl- $\beta$-D-maltopyranoside (DDM) from Protein Labelling Innovation, benzonase from Novagen, lysozyme, ampicillin, valinomycin and carbonyl cyanide $m$-chlorophenylhydrazone (CCCP) from Sigma, $\mathrm{Ni}^{2+}$ nitrilotriacetate (Ni-NTA) columns, Coomassie Brilliant Blue G250 protein-staining solution, restriction enzymes, protein ladder and Pfu DNA polymerase from Thermo Scientific, and EDTAfree protease inhibitor tablets from Roche. All other chemicals were of analytical grade.

\section{Site-directed mutagenesis}

Site-directed mutagenesis was performed on the PR gene using mismatch PCR. In brief, the pKJ900 plasmid containing PR was isolated from a $5 \mathrm{ml}$ overnight culture using the QIAprep Spin Miniprep Kit (Qiagen). The plasmid was linearized by restriction with Esp3I and subjected to mismatch PCR using overlapping primers containing the corresponding mutation sites for the D212N (DN-fwd, pKJ-rev; pKJ-fwd, DN-rev) and the F234S (FS-fwd, pKJ-rev; pKJ-fwd, FS-rev) mutations. Then, 25 cycles of PCR were run at $95^{\circ} \mathrm{C}$ for $30 \mathrm{~s}, 55^{\circ} \mathrm{C}$ for $30 \mathrm{~s}$ and $68^{\circ} \mathrm{C}$ for $1 \mathrm{~min}$. The mutant gene was further amplified using outside vector primers (pKJ-fwd, pKJ-rev) using the same PCR programme. The sequences of the primers is presented in the Supplementary Online Data. The amplified mutant gene and vector were restricted at HindIII and XbaI sites and run on an agarose gel with $0.5 \mu \mathrm{g} / \mathrm{ml}$ ethidium bromide. The bands corresponding to the restricted mutant gene and the empty vector were excised, extracted using a 
Qiagen gel extraction kit and ligated overnight at $4{ }^{\circ} \mathrm{C}$. The ligated plasmid was then transformed into E. coli UT5600.

\section{Cell transformation}

A single colony of E. coli UT5600 was inoculated into $25 \mathrm{ml}$ of LB medium and allowed to grow at $37^{\circ} \mathrm{C}$ for $4-6 \mathrm{~h}$. The cells were made competent using $\mathrm{CaCl}_{2}$ as described previously [37]. Plasmid DNA (40 ng), isolated as described above, was added to $200 \mu 1$ of competent cells and incubated on ice for $30 \mathrm{~min}$. The mixture was heat-shocked for $2 \mathrm{~min}$ at $42^{\circ} \mathrm{C}$. The cells were allowed to recover after addition of $1 \mathrm{ml}$ of SOC (Life technologies) medium for $30 \mathrm{~min}$ at $37^{\circ} \mathrm{C}$, to express ampicillin resistance. The cells were then plated on to LB agar plates containing ampicillin $(50 \mu \mathrm{g} / \mathrm{ml})$ and incubated overnight at $37^{\circ} \mathrm{C}$.

\section{Bacterial cell culture}

The cells were grown in LB medium with ampicillin selection at $30^{\circ} \mathrm{C}$ in an orbital shaker at $180 \mathrm{rev} / \mathrm{min}$. Overnight cultures were grown from frozen glycerol stocks of transformed cells, which were diluted 1:100 to obtain the working culture. At a cell density corresponding to a $\mathrm{OD}_{600}$ of $0.3-0.4$, expression of the proteorhodopsin apoprotein (opsin) was induced by the addition of IPTG to a final concentration of $1 \mathrm{mM}$. The cells were allowed to grow for a further $24 \mathrm{~h}$ at $30^{\circ} \mathrm{C}$, and then harvested.

\section{Regeneration of proteo-opsin with retinal}

Retinal stocks were stored at $-80^{\circ} \mathrm{C}$ in hexane solution, with the exception of phenyl-retinal A1, which was stored in methanol. Spectra are presented in Supplementary Figure S1. The molar absorbance values of all-trans-retinal A1 ( $\lambda_{\max } 368 \mathrm{~nm}$ in hexane) and of all-trans-retinal A2 $(385 \mathrm{~nm})$ were taken as 49000 and $44000 \mathrm{M}^{-1} \cdot \mathrm{cm}^{-1}$ respectively [38,39]. The molar absorbance values of all-E-locked retinal A1 $(395 \mathrm{~nm})$ and of all-transphenyl-retinal A1 (360 $\mathrm{nm}$ in methanol) were assumed to be similar to that of all-trans-retinal A1. At the time of use, the required aliquot of stock solution was evaporated and the residue redissolved in dimethylformamide (DMF) to obtain a concentration of $1 \mathrm{mM}$. This solution was then added to a crude cellular lysate or to isolated membrane vesicles containing the opsin to achieve a final retinal concentration of 5-10 $\mu \mathrm{M}$, and incubated under dim light for up to $60 \mathrm{~min}$ at room temperature or, if necessary, subsequently overnight at $4^{\circ} \mathrm{C}$.

\section{Preparation and analysis of membrane vesicles}

The cells were harvested by centrifugation at $3200 \mathrm{~g}$ for $20 \mathrm{~min}$ at room temperature, and the pellet was resuspended in an ice-cold solution of $50 \mathrm{mM}$ Tris/ $\mathrm{HCl}$ and $150 \mathrm{mM} \mathrm{NaCl}, \mathrm{pH} 7(10 \mathrm{ml}$ per $50 \mathrm{ml}$ of culture). The suspended cells were lysed by sonication at $4{ }^{\circ} \mathrm{C}$ using a Sonics Vibra-Cell ${ }^{\mathrm{TM}}$ sonicator for $10 \mathrm{~min}(4 \mathrm{~s}$ pulses, $5 \mathrm{~s}$ pauses, $25 \%$ amplitude) and centrifuged at $4000 \mathrm{~g}$ for $15 \mathrm{~min}$ at $4{ }^{\circ} \mathrm{C}$ to remove insoluble material and cellular debris. The resulting supernatant with membrane vesicles was incubated with the selected retinal for $1 \mathrm{~h}$ at room temperature and the vesicles were then pelleted by high-speed centrifugation $(147000 \mathrm{~g})$ for $1 \mathrm{~h}$ at $4{ }^{\circ} \mathrm{C}$. The pellet was resuspended in $150 \mathrm{mM}$ $\mathrm{NaCl}$ ( $2 \mathrm{ml}$ per $50 \mathrm{ml}$ culture). For solubilization of membrane proteins, DDM was added to a final concentration of $2 \%(\mathrm{w} / \mathrm{v})$, and the suspension was incubated with shaking for $1 \mathrm{~h}$ at $4{ }^{\circ} \mathrm{C}$, followed by overnight incubation at $4{ }^{\circ} \mathrm{C}$. The insoluble material was removed by centrifugation at $16000 \mathrm{~g}$ for $20 \mathrm{~min}$ at $4{ }^{\circ} \mathrm{C}$. The supernatant was used for spectral analysis.

\section{Proteorhodopsin purification}

The cell pellet was resuspended in ice-cold lysis buffer $(5 \mathrm{ml}$ per $100 \mathrm{ml}$ of culture) containing $20 \mathrm{mM}$ Tris/ $\mathrm{HCl}, 50 \mathrm{mM} \mathrm{NaCl}$, $20 \mathrm{mM}$ imidazole and $0.1 \% \mathrm{DDM}, \mathrm{pH} 7$, supplemented with an EDTA-free protease inhibitor tablet, benzonase (4 units $/ 100 \mathrm{ml}$ culture) and lysozyme ( $4 \mathrm{mg}$ per $100 \mathrm{ml}$ of culture). The suspension was sonicated at $4{ }^{\circ} \mathrm{C}$ and centrifuged to remove cellular debris as described in the previous section. At this stage, the crude mixture was incubated with the selected retinal for $1 \mathrm{~h}$ at room temperature. DDM was then added to a final concentration of $1.5 \%(\mathrm{w} / \mathrm{v})$ and the sample was kept rotating overnight at $4{ }^{\circ} \mathrm{C}$. The insoluble material was removed by centrifugation at $4000 \mathrm{~g}$ for $25 \mathrm{~min}$ at $4{ }^{\circ} \mathrm{C}$ and the resulting supernatant was utilized as a crude extract. For purification of the $\mathrm{His}_{6}$-tagged proteorhodopsins, immobilized metal-ionaffinity chromatography (IMAC) was exploited using $0.4 \mathrm{ml}$ of Ni-NTA resin per $100 \mathrm{ml}$ of original culture volume. The resin was contained in a spin column and first equilibrated with buffer A $(20 \mathrm{mM}$ Bis-Tris propane, $0.5 \mathrm{M} \mathrm{NaCl}$ and $0.1 \%$ DDM, pH 8) containing $20 \mathrm{mM}$ imidazole. The crude extract was then allowed to equilibrate with the column for $15 \mathrm{~min}$ at room temperature. The column was washed five times with five column volumes of buffer A containing $50 \mathrm{mM}$ imidazole at room temperature. Finally, strongly bound protein was eluted using buffer A containing $250 \mathrm{mM}$ imidazole and $0.01 \% \mathrm{DDM}$ at room temperature. Fractions of $0.3 \mathrm{ml}$ were collected. Fractions containing the purified proteorhodopsin were combined and analysed by spectroscopy and SDS/PAGE. Thus purified proteorhodopsin could be stored at $4{ }^{\circ} \mathrm{C}$ for several weeks, but was kept at $-80^{\circ} \mathrm{C}$ for long-term storage.

\section{Spectroscopy}

The spectral properties of all samples were measured using a Shimadzu UV-Vis spectrophotometer (UV-1601). In order to test the $\mathrm{pH}$-dependence of the main absorbance band of the proteorhodopsins $[9,13]$, solubilized membrane vesicles were analysed at different $\mathrm{pH}$ values by diluting the samples 1:1 with buffers containing either $100 \mathrm{mM}$ Bis-Tris propane at $\mathrm{pH} 6.5$ or 9.5 , or $20 \mathrm{mM}$ MES at $\mathrm{pH}$. To isolate the major absorbance band of the proteorhodopsin out of the composite spectrum of membrane vesicles, hydroxylamine was added from a $1 \mathrm{M}$ stock solution, $\mathrm{pH} 7$, to a final concentration of $50 \mathrm{mM}$, followed by incubation at room temperature under ambient light. Hydroxylamine attacks the Schiff base and releases the retinal from the opsin-binding pocket as retinaloxime. A difference spectrum then reveals the major absorbance band of the proteorhodopsin present. Absorbance maxima were determined using the internal peak-pick function of the software UVProbe.

\section{SDS/PAGE}

The crude and purified protein fractions were analysed by SDS/PAGE [40]. In brief, aliquots of the samples were diluted with SDS sample buffer, incubated for $30 \mathrm{~min}$ at $37^{\circ} \mathrm{C}$, and run on a $12.5 \%$ polyacrylamide gel at $20 \mathrm{~mA}$ for $2 \mathrm{~h}$. The gel was stained using Coomassie Brilliant Blue $\mathrm{G}$ for $2 \mathrm{~h}$ according to the manufacturer's instructions and destained overnight using MilliQ. Gel images were obtained using the Bio-Rad GS-800 gel imaging dock. 


\section{Starvation of cells}

Overnight cultures were diluted 1:100 to obtain a working culture of $25 \mathrm{ml}$. At a cell density corresponding to an $\mathrm{OD}_{600}$ of $0.3-0.4$, production of the proteorhodopsin was induced by the addition of IPTG to a final concentration of $1 \mathrm{mM}$ and the selected retinal to a final concentration of $5 \mu \mathrm{M}$. The cultures were allowed to grow for a further $24 \mathrm{~h}$ at $30^{\circ} \mathrm{C}$ in the dark, and then harvested. The cells were washed twice in starvation buffer $(250 \mathrm{mM} \mathrm{KCl}, 10 \mathrm{mM}$ $\mathrm{NaCl}, 10 \mathrm{mM} \mathrm{MgSO}_{4}, 100 \mu \mathrm{M} \mathrm{CaCl}_{2}$ and $10 \mathrm{mM}$ Tris/HCl, $\mathrm{pH} 7$ ) and were starved by incubation with continuous mixing for 4 days at room temperature. The cells were washed another three times and resuspended in $5 \mathrm{ml}$ of starvation buffer supplemented with a $40 \mu \mathrm{M}$ final concentration of valinomycin. The cell suspension was incubated for $30 \mathrm{~min}$ in the dark at room temperature.

\section{Proton-pumping assay}

The cell suspension was illuminated through a bandpass filter (BG-18, Schott) using a halogen light source with fibre optics (Euromex, LE.5211). An illumination level of $40 \mu$ einstein $\cdot \mathrm{m}^{-2} \cdot \mathrm{s}^{-1}$ was used throughout. Light-induced $\mathrm{pH}$ changes were measured with a pH microelectrode (SenTix ${ }^{\circledR}$ MIC, WTW) and the readout was monitored by a $\mathrm{pH}$ meter (Inolab $\mathrm{pH} 7310$, WTW) fed into a computer. The following light regime was used: 1 min dark, 1 min light, 2 min dark, 1 min light, 2 min dark. Pumping rates were calculated for $5 \mathrm{ml}$ of the cell suspension using two independent trials. Finally, CCCP was added to a final concentration of $40 \mu \mathrm{M}$ and the suspension was incubated at room temperature for $30 \mathrm{~min}$ in the dark. Light-induced $\mathrm{pH}$ changes were then measured again using the same light regime. Pumping rates were calculated as protons/s from the initial rate of the light-induced $\mathrm{pH}$ change, corrected if required for baseline drift in controls (starved cells without expression of proteo-opsin or without retinal). Molecular pumping rates could subsequently be calculated after assay of the proteorhodopsin level (see below).

\section{Determination of proteorhodopsin levels for the proton-pumping assay}

The above cell suspension from the proton-pumping assay was rinsed with starvation buffer and the pellet was resuspended in $10 \mathrm{ml}$ of buffer $\mathrm{B}(10 \mathrm{mM}$ Tris/ $\mathrm{HCl}$ and $150 \mathrm{mM} \mathrm{NaCl}$, $\mathrm{pH}$ 7). The cell suspension was sonicated as described above and the membrane vesicles and cell debris were pelleted together at $147000 \mathrm{~g}$ for $1 \mathrm{~h}$ at $4{ }^{\circ} \mathrm{C}$. The pellet was resuspended in $1.5 \mathrm{ml}$ of $150 \mathrm{mM} \mathrm{NaCl}$. DDM was added to a final concentration of $2.5 \%$ and incubated at room temperature with mixing overnight. Under these conditions, maximal extraction of proteorhodopsin was achieved without significant losses. The following day, the insoluble material was removed by centrifugation at $16000 \mathrm{~g}$ for $20 \mathrm{~min}$ at $4{ }^{\circ} \mathrm{C}$. The supernatant was used to measure an absorbance spectrum before and after bleaching with hydroxylamine as described above. The optical density value at the absorbance maximum was used to calculate the original proteorhodopsin level in the cell suspension using a molar absorbance of $45000 \mathrm{M}^{-1} \cdot \mathrm{cm}^{-1}$ [12].

\section{Construction of homology models}

A homology model for PR was built using the structure of sensory rhodopsin II (SRII) as a template (PDB code $1 \mathrm{H} 2 \mathrm{~S}$ ) [41] with which it has the highest sequence identity out of the retinal proteins for which structural information was available at that time ( $24 \%$ sequence identity). For GR, we built a model using the structure of XR as a template (PDB code 3DDL, 56\% sequence identity) [42]. Model building and subsequent analysis was performed using the WHAT IF [43] and YASARA [44] twinset with standard parameters.

\section{RESULTS}

\section{Reconstitution of proteorhodopsins with retinal analogues}

Production of proteorhodopsins following induction with IPTG and simultaneous addition of retinal A1 to the correspondingly transformed UT5600 cells could be easily verified by the red coloration of the pelleted cells or membrane vesicle preparation. However, this requires substantial amounts of retinal (up to $0.5 \mathrm{mg}$ per $100 \mathrm{ml}$ of culture) and in view of the limited quantities of retinal analogues available, we investigated other options. It eventually turned out that the apoproteins (proteoopsins) produced in vivo would still readily bind retinal A1 after harvesting the cells and preparation of membrane vesicles, thereby generating the corresponding holoproteins (proteorhodopsins). We observed that incubation of these vesicles with retinal A1 resulted in at least the same yield of proteorhodopsin as when retinal A1 was supplied to the cell culture, but required 510 -fold less retinal. Incorporation of retinal A1 as well as the analogues could be detected visually from the development of a red or purple colour (Supplementary Figure S2), and was subsequently characterized by spectroscopy after solubilization in $2 \%(\mathrm{w} / \mathrm{v})$ DDM (Figure 2A). Since the spectra of the vesicles also have contributions from other membrane components (cytochromes, excess retinal), the specific absorbance band of the proteorhodopsin was isolated by incubation with $50 \mathrm{mM}$ hydroxylamine (Figure 2B), as detailed in the Supplementary Online Data.

This procedure works well for all proteorhodopsins tested (WT PR, its double mutant PR-DNFS and GR). We observed that the PRs were much more sensitive to this 'bleaching' with hydroxylamine than GR, which may be related to the slower photocycle kinetics of PR [19,21,45]. The thus obtained absorbance maxima with retinal A1 at neutral $\mathrm{pH}$ for PR, PRDNFS and GR lie at $526 \mathrm{~nm}, 545 \mathrm{~nm}$ and $540 \mathrm{~nm}$ respectively, with an accuracy of $\pm 3 \mathrm{~nm}(n=3)$ (Figure $2 \mathrm{~B})$. These values are in good agreement with those reported in the literature $[7,13,17,46]$.

Upon incubation of the three proteo-opsin species with the retinal analogues, we observed that all three analogues regenerate the PR opsins with distinct absorbance maxima (Figure 2), whereas only two of the analogues regenerate the GR opsin (see Figure 4). Rapid incorporation of retinal A2 and all-Elocked retinal A1 was noticed, being completed within 30$60 \mathrm{~min}$ at room temperature. Incorporation of phenyl-retinal A1 was much slower, requiring additional overnight incubation at $4{ }^{\circ} \mathrm{C}$. Incorporation of retinal A2 induces an appreciable redshift of approximately $30 \mathrm{~nm}$ relative to retinal A1 in the visible absorbance band of all three proteorhodopsins. Incorporation of phenyl-retinal A1 on the other hand causes an appreciable blueshift of approximately $30 \mathrm{~nm}$ in the PR species, whereas it does not seem to generate a stable pigment with GR. This was further corroborated by the lack of a distinct negative peak after treatment of GR-opsin vesicles, incubated with phenyl-retinal A1, with hydroxylamine (results not shown). All-E-locked retinal A1 can be incorporated in all three opsins and produces only a small red-shift in the absorbance band, relative to retinal A1.

The position of the absorbance band of $\mathrm{PR}$ and reported mutants is $\mathrm{pH}$-dependent $[9,13,47]$ probably because of protonation of 
(A)

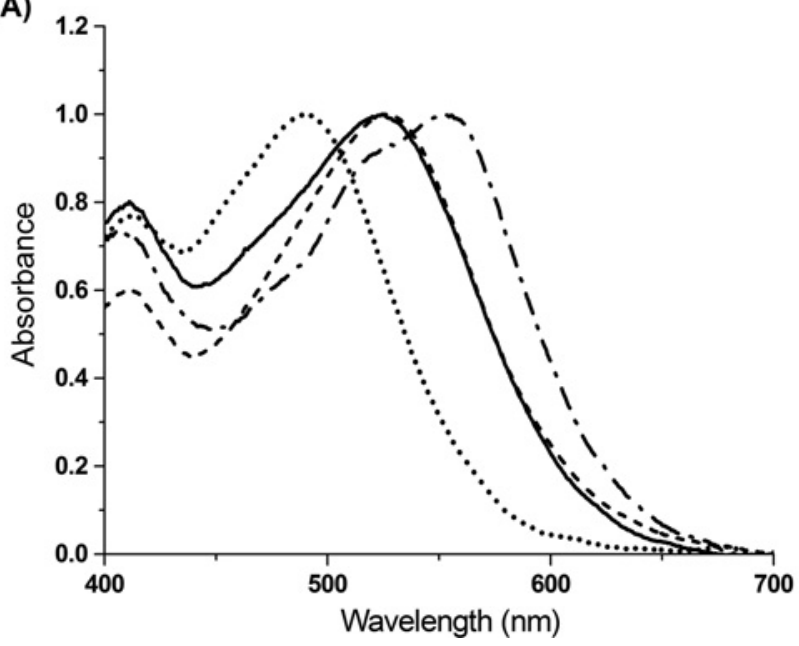

(B)

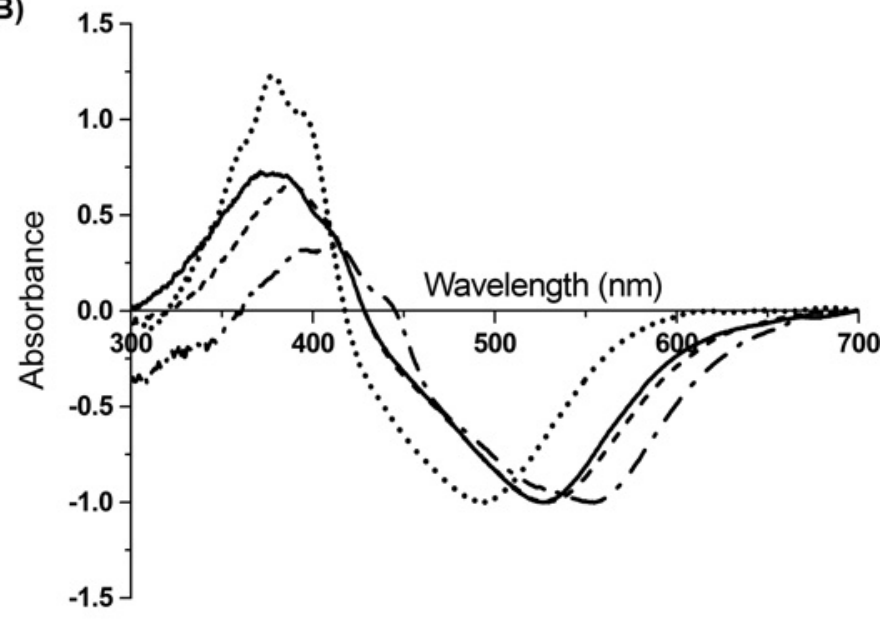

Figure 2 Spectral analysis of solubilized membrane vesicles containing PR reconstituted with the various retinals

(A) Absorbance spectra. Accuracy of the $\lambda_{\max }$ values $\pm 5 \mathrm{~nm}$. (B) Difference spectra obtained after incubation of the solubilized membrane vesicles with $50 \mathrm{mM}$ hydroxylamine. The absorbance bands of the proteorhodopsins are seen here as negative peaks, whereas the positive peaks between 360 and $400 \mathrm{~nm}$ are due to the formation of the retinaloximes. Accuracy of the $\lambda_{\text {max }}$ values was $\pm 3 \mathrm{~nm}$. PR with retinal A1, absorbance maximum at $\sim 520 \mathrm{~nm}(\mathbf{A})$ and $526 \mathrm{~nm}(\mathbf{B}) ;-$ - - PR with retinal A2, absorbance maximum at $\sim 560 \mathrm{~nm}(\mathbf{A})$ and $555 \mathrm{~nm}(\mathbf{B})$ with a shoulder at $\sim 530 \mathrm{~nm} ;$ _ _ - . PR with all-E-locked retinal A1, absorbance maximum at $\sim 520 \mathrm{~nm}(\mathbf{A})$ and $529 \mathrm{~nm}(\mathbf{B}) . . . . . .$. . PR with phenyl-retinal A1, absorbance maximum at $\sim 490 \mathrm{~nm}(\mathbf{A})$ and $494 \mathrm{~nm}(\mathbf{B})$.

the proton-acceptor residue $\mathrm{Asp}^{97}[12,48]$ which induces a redshift of $25-30 \mathrm{~nm}$. The corresponding $\mathrm{p} K_{\mathrm{a}}$ values for PR and PR-DNFS are reported to be 7.3 and 8.0 respectively [13]. Such a strong $\mathrm{pH}$-dependence has not yet been observed for GR $[21,22,49]$. We were interested in whether the analogue pigments would show a similar behaviour, and recorded the absorbance spectra of the corresponding solubilized membrane vesicles at pH 5, 6.5 and 9.5 (Supplementary Table S1). All PRbased analogue pigments showed a clear $\mathrm{pH}$-dependence of their visible absorbance band. The largest red-shift upon going from $\mathrm{pH} 9.5$ to 5 of approximately $25 \mathrm{~nm}$ was observed for the all$E$-locked retinal A1 analogue of PR. The magnitude of the shift between $\mathrm{pH} 9.5$ and 5 will also depend on the $\mathrm{p} K_{\mathrm{a}}$ value. An accurate determination of this $\mathrm{p} K_{\mathrm{a}}$ in various PR-based analogue pigments is the subject of a follow-up study and outside the scope of the present study. On the other hand, we did not observe a significant $\mathrm{pH}$ effect in this range on the absorbance profile of GR or of the GR-based analogue pigments.

\section{Purification of the proteorhodopsins}

Following their characterization in membrane vesicles, we aimed for optimal spectral characterization of the native and analogue pigments by purification over an Ni-NTA resin exploiting their C-terminal $\mathrm{His}_{6}$ tag. According to the ratio $A_{280} / A_{5 \mathrm{xx}}$ in the absorbance spectra, which varied between 1.5 and 2.5 for all pigments, and the strong band at $\sim 25 \mathrm{kDa}$ for PR (Supplementary Figure S3) and at $\sim 27 \mathrm{kDa}$ for GR (results not shown) observed upon SDS/PAGE analysis, we conclude that a high degree of purification was achieved for all pigments. The purified fractions remained spectrally stable for several weeks at $4{ }^{\circ} \mathrm{C}$.

Purified PR, PR-DNFS and GR show $\lambda_{\max }$ values of $522 \mathrm{~nm}$, $540 \mathrm{~nm}$ and $543 \mathrm{~nm}$ with retinal A1 respectively (Figures 3 and 4, and Supplementary Figure S4), in excellent agreement with literature data $[13,46]$ and in close agreement with the vesicle data. Incorporation of retinal A2 induces a large redshift of approximately $30 \mathrm{~nm}$ in the specific absorbance band of all three proteorhodopsins to $\lambda_{\max }$ values of $554 \mathrm{~nm}, 568 \mathrm{~nm}$ and $575 \mathrm{~nm}$ for PR, PR-DNFS and GR respectively. In contrast, phenyl-retinal A1 induces a blue-shift of at least $30 \mathrm{~nm}$ in PR and PR-DNFS to $493 \mathrm{~nm}$ and $501 \mathrm{~nm}$ respectively. No specific absorbance band was seen for GR purified after incubation with this analogue. SDS/PAGE analysis revealed that the opsin was purified successfully, which strengthens our conclusion that the GR opsin is not able to stably bind phenyl-retinal A1, or this analogue pigment is not stable under our experimental conditions. Incorporation of all- $E$-locked retinal A1 induces a small redshift of approximately $5 \mathrm{~nm}$ in all analogue pigments to $526 \mathrm{~nm}$, $545 \mathrm{~nm}$ and $548 \mathrm{~nm}$ for PR, PR-DNFS and GR respectively. These data are compiled in Table 1.

\section{Proton pump activity of reconstituted proteorhodopsins}

Although membrane vesicles are more economical with respect to ligand usage, we find them less suitable for a quantitative proton-pumping assay. We were not able to isolate vesicle preparations with largely right-side-out- or inside-out-oriented proteorhodopsin. In addition, isolated vesicles can be more or less leaky. Hence we opted to use intact E. coli cells instead. However, the activity of proteorhodopsins is not easily reproducibly assayed in viable $E$. coli cells. The proton electromotive force is used to drive metabolic processes (e.g. ATP synthesis by ATP synthase) and may trigger opening of voltage-gated proton channels in the E. coli membrane [9]. To avoid such complications, the cells were starved for a few days, with the most reproducible results obtained after 4-5 days of starvation. The proton pump activity of the native proteorhodopsins and their analogue pigments was measured in starved cell suspensions in the presence of the $\mathrm{K}^{+}$ionophore valinomycin and $\mathrm{K}^{+}$ions, which eliminates the electrical component of the electrochemical proton gradient. This allows quantification of the proton efflux mediated by the proteorhodopsins, without interference by any possible back-pressure effects of the transmembrane electrical potential gradient. For the cells producing proteorhodopsin, this was seen 


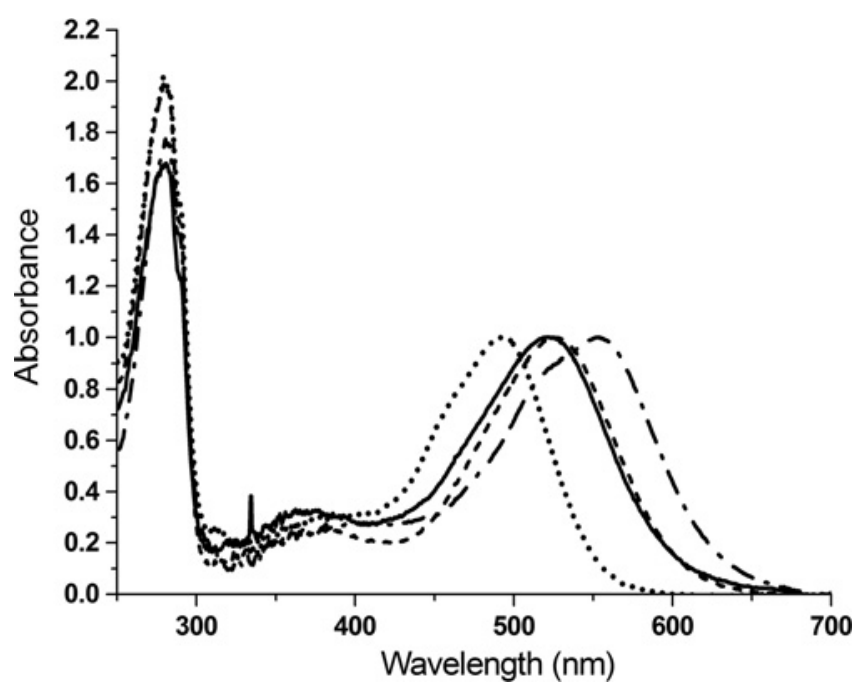

Figure 3 Absorbance spectra of purified PR and its analogues

The absorbance at $280 \mathrm{~nm}$ largely arises from the aromatic residues of the protein. The $A_{280} / A_{5 x x}$ ratios are all $<2$, indicating a high degree of purity. Spectra were taken at pH 8 . Accuracy of the $\lambda_{\max }$ values was $\pm 2 \mathrm{~nm}$. _ PR with retinal A1, absorbance maximum at $522 \mathrm{~nm}$; - . PR with retinal A2, absorbance maximum at $554 \mathrm{~nm}$, with a shoulder at $\sim 520 \mathrm{~nm}$; - . - PR with all-E-locked retinal A1, absorbance maximum at $526 \mathrm{~nm} ; . . . . .$. . PR with phenyl-retinal A1, absorbance maximum at $493 \mathrm{~nm}$.

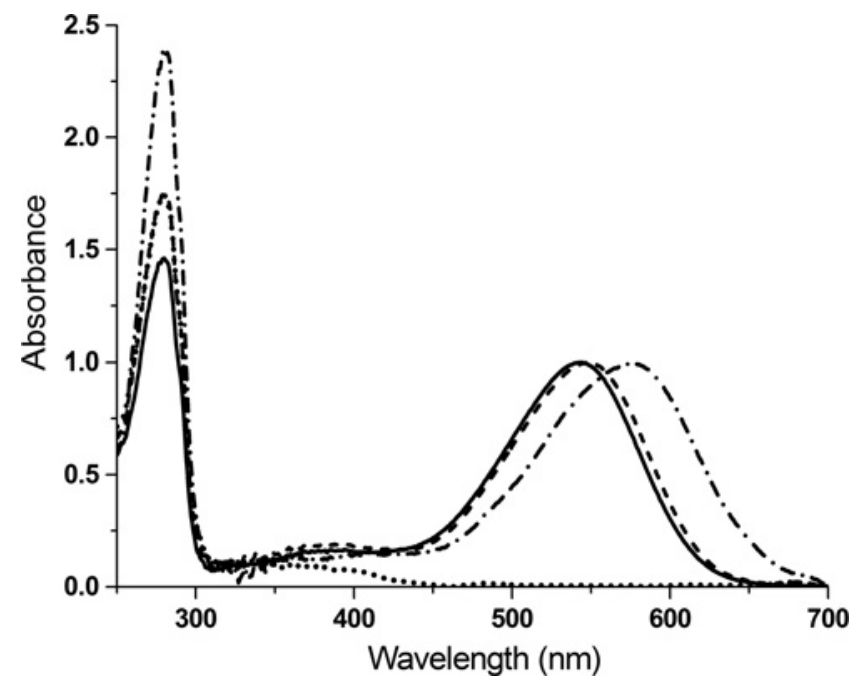

Figure 4 Absorbance spectra of purified GR and its analogues

The $A_{280} / A_{5 x x}$ ratios are all $<2.5$. Spectra were taken at $\mathrm{pH} 8$. Accuracy of the $\lambda_{\max }$ values was $+2 \mathrm{~nm}$. No specific peak around $500 \mathrm{~nm}$ was obtained with the phenyl-retinal A1 analogue

- GR with retinal A1, absorbance maximum at $543 \mathrm{~nm}$; _. . GR with retinal A2, absorbance maximum at $575 \mathrm{~nm}$, with a hint of a shoulder near $540 \mathrm{~nm} ; \ldots$. . G GR with all-E-locked retinal A1, absorbance maximum at $548 \mathrm{~nm} ; . . . . .$. . GR with phenyl-retinal A1, only a protein peak near $280 \mathrm{~nm}$ was observed.

as a decrease in $\mathrm{pH}$ upon illumination, which slowly returned to the baseline value in darkness. We did not try to optimize conditions to achieve maximal pumping rates (spectral range, photon intensity, cell density), since this is outside the scope of the present study. Instead, for mutual comparison, the calculated rates were normalized relative to the most active A1 rhodopsin (GR).

Representative traces for PR and its three analogue pigments are shown in Figure 5, and the normalized pumping rates in Table 1 . The highest pumping rates obtained with the native

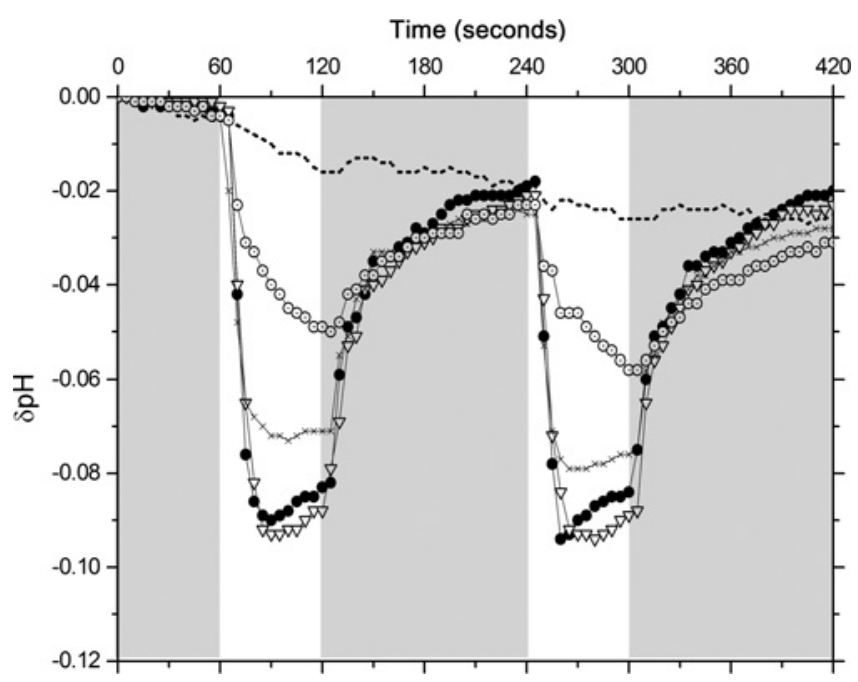

Figure 5 Proton-pumping traces of starved $E$. coli UT5600 cell suspensions containing PR or one of its analogues

$\mathrm{pH}$ readings were acquired every $5 \mathrm{~s}$ after an equilibration period of $1 \mathrm{~min}$, followed by illumination (white area) for $1 \mathrm{~min}$, and darkness (grey area) for $2 \mathrm{~min}$. The levels of the various pigments varied in the experiments. Hence the calculated initial rates of the traces were divided by the pigment concentration to arrive at molecular pumping rates............ control $E$. coli UT5600 cells containing the proteo-opsin without retinal; $\longrightarrow-$ E. coli UT5600 cells containing PR with retinal $A 1 ; \longrightarrow \nabla$, E. coli UT5600 cells containing PR with retinal A2; $\longrightarrow$ - E. coli UT5600 cells containing PR with all-E-locked retinal A1; ——, E. coli UT5600 cells containing PR with phenyl-retinal A1.

ligand retinal A1 were observed for GR (4-5 protons $\left.\cdot \mathrm{mol}^{-1} \cdot \mathrm{s}^{-1}\right)$, which corroborates findings from previous studies [21,22,50]. The lowest pumping activity of the three proteorhodopsin species was observed for the PR-DNFS mutant, which retains 40-60\% pumping activity of the WT. This is consistent with previous data using sphaeroplast suspensions [13]. Interestingly, with retinal $\mathrm{A} 2$ or all- $E$-locked retinal $\mathrm{A} 1$ as the chromophore, all three proteorhodopsins presented proton pump activity very similar to that with retinal A1, indicating that these analogues do not perturb the proton translocation mechanism. Also, the phenyl-retinal A1 analogue retains significant proton pump activity for both $\mathrm{PR}$ and PR-DNFS.

All light-induced $\mathrm{pH}$ changes were largely prevented by the addition of $40 \mu \mathrm{M}$ protonophorous uncoupler CCCP. In addition, no light-induced $\mathrm{pH}$ changes were observed for the control situation, where the opsin expression was not induced but retinal was present (results not shown), or the converse, i.e. when the opsin was expressed but retinal not added (Figure 5). Taken together, this indicates that the measured pumping rates are a result of the light-induced proton efflux mediated by the respective proteorhodopsins.

\section{Homology models of PR and GR}

In order to evaluate the effect of retinal analogues and mutations, a 3D structure of PR and GR would be very useful. However, a crystal structure is not available for these retinal proteins and the PR structure solved using NMR spectroscopy [51] significantly deviates even in the transmembrane domain from the crystal structures of other microbial retinal proteins [18,52] and from earlier PR homology models based on the BR structure [53,54]. Hence we decided to generate homology models for GR and PR, based on the crystal structures of retinal proteins with which they had the highest sequence identity at that time (XR and 
SRII respectively). The resulting models for PR and GR show high similarity in the structure of the transmembrane domain and the binding pocket, but, as expected, show variation in the loop regions. Recently, a crystal structure was published for a blue-PR having $83 \%$ sequence identity with PR [18] (PDB code 4KNF). A comparison of this structure with our homology model for PR, presented in Figure 6(A), shows excellent conformity in the $\alpha$ helical domain, and a RMSD of only $1.8 \AA$ ( $1 \AA=0.1 \mathrm{~nm})$ over all identical residues.

\section{DISCUSSION}

\section{Proteorhodopsin selection}

PR and, to a lesser extent, GR have been extensively characterized with their native ligand all-trans-retinal A1. We obtained good expression levels in the E. coli strain UT5600 (at least $10 \mathrm{mg} / \mathrm{l}$ for PR and $4 \mathrm{mg} / \mathrm{l}$ for $\mathrm{GR}$ ). The proteorhodopsins produced could be purified to a high degree. Furthermore, we obtained good agreement between the $\lambda_{\max }$ values obtained from the absorbance spectra of the purified protein, and the difference spectrum obtained after bleaching the solubilized membrane vesicle fraction with hydroxylamine.

The spectral characteristics of a retinylidene chromophore are strongly affected by its interaction with protein residues lining its binding pocket. However, residues can also exert their effect on the chromophore from a distance, via their involvement in the secondary structure of the protein or their contribution to the local electrostatic field. This is exemplified in the D212N/F234S double mutant of PR, which has been described previously [13]. The authors report that mutation of the binding pocket residue $\mathrm{Phe}^{234}$ to serine causes a red-shift of the main absorbance band and strongly reduces proton pump activity. According to our homology model, $\mathrm{Asp}^{212}$ is located in interhelical loop E-3 and it is not surprising that the single mutation D212N does not change the absorbance or pumping activity of PR [13] (results not shown). However, when these mutations are combined, this yields a red-shifted PRDNFS that retains significant proton pump activity. We could fully reproduce these characteristics and included this double mutant in the present study to test whether spectral shifts induced by a mutation are complementary to those implemented by retinal analogues. With PR-DNFS, expression yields of at least $6 \mathrm{mg} / \mathrm{l}$ of UT5600 culture were obtained.

\section{Analogue pigments}

To our knowledge, no detailed study has been reported to date on the effect of retinal analogues on molecular properties of PR or GR. In the context of a wide-angle scattering study of PR the 13-desmethyl,13-iodo-retinal A1 analogue was tested and shown to induce a $23 \mathrm{~nm}$ red-shift [54]. In the present study, we focus on ring modifications.

Incorporation of retinal $\mathrm{A} 2$ is expected to red-shift the absorbance band relative to bound retinal A1 [38,55] (Supplementary Online Data). This has been demonstrated previously in archaeal and channel rhodopsins (ChRs), where red-shifts of approximately $30 \mathrm{~nm}$ are reported, with only a small effect on proton pumping or channel functionality [26-29], as well as in XR with a $23 \mathrm{~nm}$ red-shift [30]. As anticipated, this analogue reacted rapidly to completeness with all three proteo-opsins within $30 \mathrm{~min}$ at room temperature (results not shown), and induced comparable red-shifts of approximately $30 \mathrm{~nm}$ corresponding to an energy difference of approximately $1100 \mathrm{~cm}^{-1}$ (Table 1). The resulting A2 analogue pigments were quite stable in detergent 
(A)

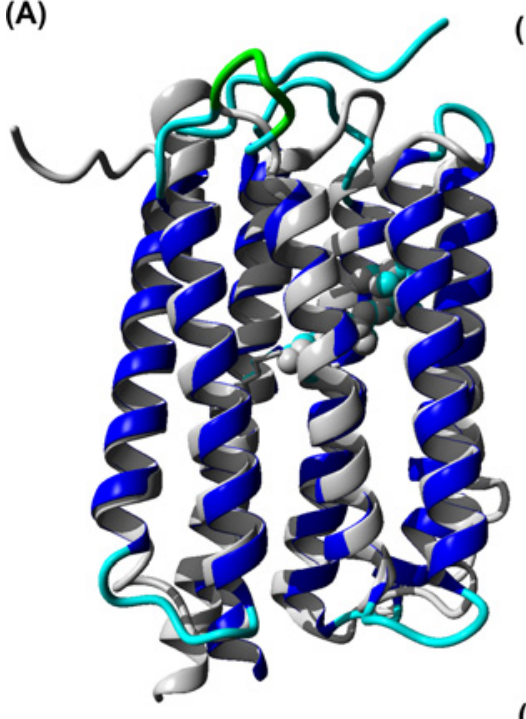

(B)

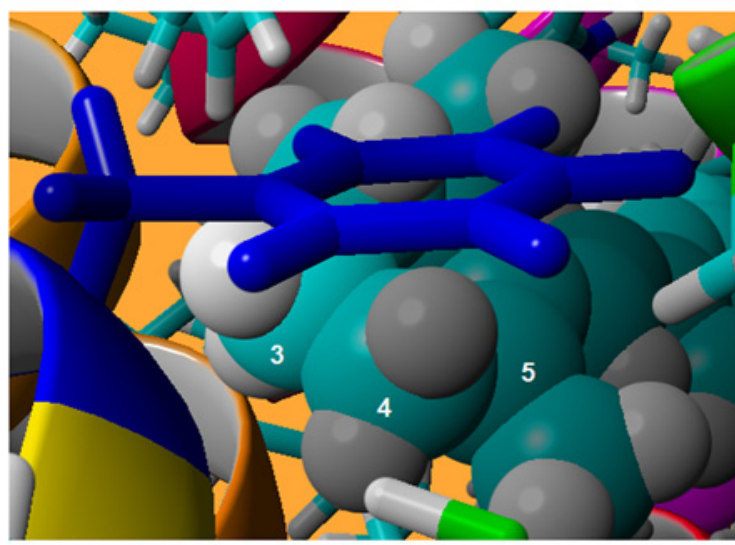

(C)

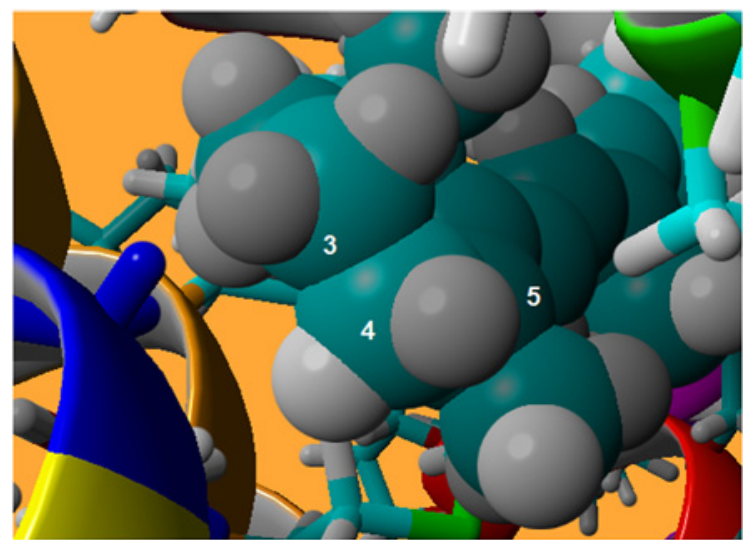

\section{Figure 6 Homology models of PR and GR}

(A) Overlay of the backbone of the PR homology model (blue) with that of the recently published blue-light-absorbing PR structure (grey) [23] (PDB code 4KNF). The carbon atoms of the retinal moiety are represented by the small spheres with the ring element at the upper right. The image was generated with YASARA (http://www.yasara.org). (B and C) Rear view of the binding pocket in the (B) PR and (C) GR homology models. In PR, the dark blue residue represents Phe ${ }^{152}$ which is situated above the ring of retinal A1 (carbons as blue-green spheres; some ring carbons are numbered). In the case of GR, this position contains the smallest possible side chain (Gly ${ }^{178}$; dark blue).

solution and could be purified to a high degree (Figures 3 and 4 , and Supplementary Figures S3 and S4).

The A2 analogue pigments also present a slightly broadened absorbance band with a small shoulder at the hypsochromic wing of the spectrum (at approximately $510 \mathrm{~nm}$ for PR and approximately $530 \mathrm{~nm}$ for the other two analogue pigments). Such a shoulder was observed previously in the A2 analogues of BR [26], ChR and archaerhodopsin 3 (AR3) [29]. It is most likely that this shoulder represents fine structure of vibronic origin, possibly due to a more rigid conformation [33], e.g. also evident in the spectrum of all-E-locked retinal A1 in Supplementary Figure S1. An important observation is that retinal A2 is fully equivalent to retinal A1 in maintaining proton pump activity in all three proteorhodopsins (Figure 5 and Table 1).

In all-E-locked retinal $\mathrm{A} 1$, the polyene system is locked in the 6-s-trans configuration effectuating optimal conjugation. This analogue was previously tested on bacterio-opsin and xanthoopsin, to study the effect of the configuration about the C6-C7 single bond [35]. It was observed that the 6-s-trans form of this compound smoothly reacted with both opsins, but the 6-s-cis form did not. The 6-s-trans analogue provided spectral properties very similar to those of native $\mathrm{BR}$ and XR, and retained $90 \%$ of the pumping activity of BR. This corroborated previous solid-state NMR studies indicating that retinal A1 has taken up a 6-s-trans configuration upon binding to bacterio-opsin [56]. The transition from the twisted 6-s-cis in the free retinal A1 to the planar 6- s-trans form in the binding pocket of the protein accounts for a part of the spectral shift in the binding site. In all-E-locked retinal A1, the 6-s-trans form has already been enforced, which explains its red-shifted absorbance band relative to free retinal A1 (Supplementary Figure S1) and its small effect on the absorbance band when bound in BR or XR. The all-E-locked retinal A1 was not tested previously on PR or GR. This analogue reacted with all three proteo-opsins, reaching completion within 30-60 min at room temperature. The resulting analogue pigments exhibit only small red-shifts relative to the native pigments $(4-5 \mathrm{~nm})$. These results provide strong evidence that, in bacterial rhodopsins, the retinal ligand is bound in the 6-s-trans configuration as well. This implies that the bathochromic shift of the absorbance band in XR and archaeal rhodopsins relative to these bacterial rhodopsins is largely induced by the protein environment. All three proteorhodopsin analogues containing all- $E$-locked retinal A1 retained strong proton pump activity. This would render this retinal analogue interesting for optogenetic applications. It can be supplied directly or in precursor form in the diet and will hardly interfere with the visual system. In addition, it may be less prone to generate metabolic products such as retinoic acids with strong signalling function.

Phenyl-retinal A1 was previously reported to react very slowly with bacterio-opsin, yielding a strongly blue-shifted analogue pigment $[31,32]$. In the case of the bacterial opsins, phenylretinal A1 behaves quite differently from the other two analogues. 
It forms a stable pigment with the PR and PR-DNFS opsins, but not with the GR opsin. Furthermore, it regenerates the PR opsins slowly, with only partial regeneration after $60 \mathrm{~min}$ of incubation at room temperature, requiring additional overnight incubation at $4{ }^{\circ} \mathrm{C}$. Finally, it induced a significant blue-shift in absorbance, compared with retinal A1. The slow regeneration is most likely to be due to a poor fit in the opsin-binding pocket because of the absence of the methyl groups on the ring element, which contribute sterically to correct positioning and stabilization of the ring and to its interaction with its protein environment $[33,57]$. Nevertheless, the resulting analogue pigments maintained significant proton pump activity and could be purified successfully.

The structural models we generated for GR and PR may present a clue to understanding their different reactivity with phenylretinal A1. Figure 6(B) shows the models for the rear end of the binding pockets. The most striking difference is seen at the position of $\mathrm{Phe}^{152}$ in PR, where GR has a glycine residue $\left(\mathrm{Gly}^{178}\right)$. This difference is physiologically relevant, since it was demonstrated that mutating Gly ${ }^{178}$ in GR to a bulkier tryptophan residue abolished strong binding of a carotenoid (echinenone), which is involved in energy transfer to the retinal [21,58,59], and eliminated this energy transfer. The smaller glycine residue at position 178 apparently is required to allow enough space for immobilizing the carotenoid ring [33,42], thereby allowing energy transfer and increasing the cross-section for photo-activation of retinal. We surmise that the aromatic ring of $\mathrm{Phe}^{152}$ in $\mathrm{PR}$, which is positioned right above the ring element of retinal, would contribute significant $\pi-\pi$ stacking interaction. Together with the methyl groups on the polyene chain, this may sufficiently stabilize this analogue in the binding pocket. GR cannot provide this stacking interaction, and thus may not provide sufficient interaction energy or too much motional freedom for the phenylretinal A1 to form a stable protonated Schiff base. We will verify this hypothesis by testing whether the G178F mutant of GR will yield a stable pigment with phenyl-retinal A1.

In this context, a comparison with XR, a distant relative of GR, is appropriate, since XR also binds a carotenoid (salinixanthin, a derivative of echinenone) [60]. The position equivalent to $\mathrm{Gly}^{178}$ in GR carries the same residue in XR (Gly $\left.{ }^{156}\right)$. Xanthoopsin is reported to react slowly with phenyl-retinal A1 in the presence of bound salinixanthin, generating a stable pigment [30]. Possibly, the presence of the carotenoid ring sufficiently stabilizes phenyl-retinal A1 in the binding pocket. Since there is no echinenone available in our $E$. coli expression system, it needs to be investigated whether complementation with echinenone would result in a stable analogue pigment of GR with phenylretinal A1. It has been suggested that carotenoid fixation is required for pigment formation in XR $[33,61]$. Our results show that this is not the case for GR, which easily generates analogue pigments that retain full proton-pumping capacity.

\section{Conclusions and future prospects}

Our results demonstrate that ring modification can affect the affinity of the analogue for the retinal-binding site and will usually modulate the spectral properties of the respective rhodopsin, but, importantly, can largely maintain proton pump activity. This presents good prospects for further modification trials in the ring and eventual biotechnological applications. The smooth reaction with all-E-6-s-trans-locked retinal while implementing only a small red-shift corroborates available evidence that the retinal chromophore in bacterial rhodopsins is also bound in the 6-s-trans configuration. We show further that the spectral shifts effected by the analogues can be additive to spectral shifts induced by mutagenesis. Hence combining selected mutagenesis with ligand analogues offers promising prospects for further extending the wavelength range of rhodopsins.

Retinal analogues also present attractive prospects for application in the field of optogenetics. Electrogenic microbial rhodopsins (ion pumps and ChRs) are widely used to modulate the activity of neurons and other cells by light $[62,63]$. Chromophore substitution provides a complementary strategy to improve the flexibility of these optogenetic tools, e.g. allowing multiphoton excitation or improved light penetration in biological tissues. For instance, supplementation with all-E-6-s-trans-locked retinal A2 would allow the red-shifting of microbial rhodopsins, probably, as argued above for its A1 counterpart, without significant interference with the visual system and with signalling metabolites of retinal A1.

The non-pumping mutant PR-D97N was recently engineered as a sensor of the membrane potential in bacteria [64]. Spectral modulation of such sensors using chromophore substitution towards specific spectral ranges would have widespread electrophysiological applications in systems that are difficult or too small to study with traditional methods (bacteria, neuronal compartments, mitochondria or other cellular organelles).

\section{AUTHOR CONTRIBUTION}

Srividya Ganapathy and Willem de Grip designed the study and wrote the paper. Srividya Ganapathy, Odette Bécheau and Siebren Frölich tested retinal analogues on the proteorhodopsin species. Hanka Venselaar constructed the homology models. Sarah Radwan contributed to the characterization of proteorhodopsins in E. coli. Johan Lugtenburg synthesized the retinal analogues. Jeroen van der Steen, Que Chen, Klaas Hellingwerf and Huub de Groot contributed towards the design of experiments, and the writing and discussion of the paper.

\section{ACKNOWLEDGEMENTS}

Sincere thanks to Hans den Dulk (Leiden Institute of Chemistry) for his sound technical advice and support throughout the course of this work.

\section{FUNDING}

We gratefully acknowledge the BioSolar Cells (BSC) consortium and Leiden University for providing financial support towards this research. The project was carried out within the research programme of BioSolar Cells [BSC core project grant C2.9], co-financed by the Dutch Ministry of Economic Affairs.

\section{REFERENCES}

1 Ruiz-González, M.X. and Marín, I. (2004) New insights into the evolutionary history of type 1 rhodopsins. J. Mol. Evol. 58, 348-358 CrossRef PubMed

2 Sharma, A.K., Spudich, J.L. and Doolittle, W.F. (2006) Microbial rhodopsins : functional versatility and genetic mobility. Trends Microbiol. 14, 463-469 CrossRef PubMed

3 Grote, M., Engelhard, M. and Hegemann, P. (2014) Of ion pumps, sensors and channels: perspectives on microbial rhodopsins between science and history. Biochim. Biophys. Acta 1837, 533-545 CrossRef PubMed

4 Oesterhelt, D. and Stoeckenius, W. (1971) Rhodopsin-like protein from the purple membrane of Halobacterium halobium. Nature 233, 149-152 PubMed

5 Stoeckenius, W. and Bogomolni, R.A. (1982) Bacteriorhodopsin and related pigments of halobacteria. Annu. Rev. Biochem. 52, 587-616 CrossRef

6 Lanyi, J.K. (2004) Bacteriorhodopsin. Annu. Rev. Physiol. 66, 665-688 CrossRef PubMed

7 Béjà, 0., Aravind, L., Koonin, E.V., Suzuki, M.T., Hadd, A., Nguyen, L.P., Jovanovich, S.B. Gates, C.M., Feldman, R.A., Spudich, J.L. et al. (2000) Bacterial rhodopsin: evidence for a new type of phototrophy in the sea. Science 289, 1902-1906 CrossRef PubMed

8 Fuhrman, J.A., Schwalbach, M.S. and Stingl, U. (2008) Proteorhodopsins: an array of physiological roles? Nature 6, 488-494 
9 Wang, W.W., Sineshchekov, O.A., Spudich, E.N. and Spudich, J.L. (2003) Spectroscopic and photochemical characterization of a deep ocean proteorhodopsin. J. Biol. Chem. 278, 33985-33991 CrossRef PubMed

10 Martinez, A., Bradley, A.S., Waldbauer, J.R., Summons, R.E. and Delong, E.F. (2007) Proteorhodopsin photosystem gene expression enables photophosphorylation in a heterologous host. Proc. Natl. Acad. Sci. U.S.A. 104, 5589-5595 CrossRef

11 Walter, J.M., Greenfield, D., Bustamante, C. and Liphardt, J. (2007) Light-powering Escherichia coli with proteorhodopsin. Proc. Natl. Acad. Sci. U.S.A. 104, 2408-2412 CrossRef PubMed

12 Friedrich, T., Geibel, S., Kalmbach, R., Chizhov, I., Ataka, K., Heberle, J., Engelhard, M. and Bamberg, E. (2002) Proteorhodopsin is a light-driven proton pump with variable vectoriality. J. Mol. Biol. 321, 821-838 CrossRef PubMed

13 Kim, S.Y., Waschuk, S.A., Brown, L.S. and Jung, K.H. (2008) Screening and characterization of proteorhodopsin color-tuning mutations in Escherichia coli with endogenous retinal synthesis. Biochim. Biophys. Acta 1777, 504-513 CrossRef PubMed

14 Gourdon, P., Alfredsson, A., Pedersen, A., Malmerberg, E., Nyblom, M., Widell, M., Bertsson, R., Pinhassi, J., Braiman, M., Hansson, Ö. et al. (2008) Optimized in vitro and in vivo expression of proteorhodopsin: a seven-transmembrane proton pump. Protein Expr. Purif. 58, 103-113 CrossRef PubMed

15 Gómez-Consarnau, L., González, J.M., Coll-Lladó, M., Gourdon, P., Pascher, T., Neutze, R., Pedrós-Alió, C. and Pinhassi, J. (2007) Light stimulates growth of proteorhodopsincontaining marine flavobacteria. Nature $\mathbf{4 4 5}, 210-213$ CrossRef PubMed

16 Gómez-Consarnau, L., Akram, N., Lindell, K., Pedersen, A., Neutze, R., Milton, D.L., González, J. and Pinhassi, J. (2010) Proteorhodopsin phototrophy promotes survival of marine bacteria during starvation. PLoS Biol. 8, 2-11

17 Béjà, O., Spudich, E.N., Spudich, J.L., Leclerc, M. and DeLong, E.F. (2001) Proteorhodopsin phototrophy in the ocean. Nature 411, 786-789 CrossRef PubMed

18 Ran, T., Ozorowski, G., Gao, Y., Sineshchekov, O.A., Weiwu, W., Spudich, J.L. and Luecke, H. (2013) Cross-protomer interaction with the photoactive site in oligomeric proteorhodopsin complexes. Acta Crystallogr. D Biol. Crystallogr. 69, 1965-1980 CrossRef PubMed

19 Dioumaev, A.K., Brown, L.S., Shih, J., Spudich, E.N., Spudich, J.L. and Lanyi, J.K. (2002) Proton transfers in the photochemical reaction cycle of proteorhodopsin. Biochemistry 41, 5348-5358 CrossRef PubMed

20 Nakamura, Y., Kaneko, T., Sato, S., Mimuro, M., Miyashita, H., Tsuchiya, T., Sasamoto, S., Watanabe, A., Kawashima, K., Kishida, Y. et al. (2003) Complete genome structure of Gloeobacter violaceus PCC 7421, a cyanobacterium that lacks thylakoids. DNA Res. $\mathbf{1 4 5}$ 137-145 CrossRef

21 Miranda, M.R.M., Choi, A.R., Shi, L., Bezerra, Jr, A.G., Jung, K.-H. and Brown, L.S. (2009) The photocycle and proton translocation pathway in a cyanobacterial ion-pumping rhodopsin. Biophys. J. 96, 1471-1481 CrossRef PubMed

22 Vogt, A., Wietek, J. and Hegemann, P. (2013) Gloeobacter rhodopsin, limitation of proton pumping at high electrochemical load. Biophys. J. 105, 2055-2063 CrossRef PubMed

23 Sheves, M., Albeck, A., Friedman, N. and Ottolenghi, M. (1986) Controlling the $p K_{a}$ of the bacteriorhodopsin Schiff base by use of artificial retinal analogues. Proc. Natl. Acad. Sci. U.S.A. 83, 3262-3266 CrossRef PubMed

24 Baasov, T. and Sheves, M. (1986) Alteration of $p K_{a}$ of the bacteriorhodopsin protonated Schiff base: a study with model compounds. Biochemistry 25, 5249-5258 CrossRef

25 Gat, Y. and Sheves, M. (1993) A mechanism for controlling the $p K_{a}$ of the retinal protonated Schiff base in retinal proteins: a study with model compounds. J. Am. Chem. Soc. 115, 3772-3773 CrossRef

26 Tokunaga, F. and Ebrey, T. (1978) The blue membrane: the 3-dehydroretinal-based artificial pigment of the purple membrane. Biochemistry 17, 1915-1922 CrossRef PubMed

27 Spudich, J.L., McCain, D.A., Nakanishi, K., Masami, O., Shimizu, N., Rodman, H., Honig, B. and Bogomolni, R.A. (1986) Chromophore/protein interaction in bacterial sensory rhodopsin and bacteriorhodopsin. Biophys. J. 49, 479-483 CrossRef PubMed

28 Iwasa, T. (1992) Artificial pigments of halorhodopsin and their chloride pumping activities. Biochemistry 31, 1190-1195 CrossRef PubMed

29 Sineshchekov, O.A., Govorunova, E.G., Wang, J. and Spudich, J.L. (2012) Enhancement of the long-wavelength sensitivity of optogenetic microbial rhodopsins by 3,4-dehydroretinal. Biochemistry 51, 4499-4506 CrossRef PubMed

30 Smolensky, E. and Sheves, M. (2009) Retinal-salinixanthin interactions in xanthorhodopsin: a circular dichroism (CD) spectroscopy study with artificial pigments. Biochemistry 48, 8179-88 CrossRef PubMed

31 Derguini, F., Bigge, C.F., Croteau, A.A., Balogh-Nair, V. and Nakanishi, K. (1984) Visual pigments and bacteriorhodopsins formed from aromatic retinal analogs. Photochem. Photobiol. 39, 661-665 CrossRef PubMed

32 Maeda, A., Asato, A.E., Liu, R.S.H. and Yoshizawa, T. (1984) Interaction of aromatic retinal analogues with apopurple membranes of Halobacterium halobium. Biochemistry 23 2507-2513 CrossRef PubMed
33 Smolensky-Koganov, E., Hirshfeld, A. and Sheves, M. (2013) Retinal $\beta$-ionone ring-salinixanthin interactions in xanthorhodopsin: a study using artificial pigments. Biochemistry 52, 1290-1301 CrossRef PubMed

34 van der Steen, R., Biesheuvel, P.L., Mathies, R.A. and Lugtenburg, J. (1986) Retinal analogues with locked 6-7 conformations show that bacteriorhodopsin requires the 6-s-trans conformation of the chromophore. J. Am. Chem. Soc. 108, 6410-6411 CrossRef

35 van Wijk, A.A.C., van de Weerd, M.B. and Lugtenberg, J. (2003) Synthetic scheme for the preparation of ${ }^{13} \mathrm{C}$-labeled 3,4-didehydro-retinal, 3-hydroxyretinal, and 4-hydroxyretinal up to uniform ${ }^{13} \mathrm{C}$-enrichment. Eur. J. Org. Chem. 2003, 863-868 CrossRef

36 Lugtenburg, J., Creemers, A.F.L., Verhoeven, M.A., van Wijk, A.A.C., Verdegem, P.J.E. Monnee, M.C.F. and Jansen, F.J.H.M. (1999) Synthesis of ${ }^{13} \mathrm{C}$-labeled carotenoids and retinoids. Pure Appl. Chem. 71, 2245-2251 CrossRef

37 Maniatis, T., Fritsch, E.F. and Sambrook, J. (1982) In Molecular Cloning: a Laboratory Manual, Cold Spring Harbor Laboratory Press, Cold Spring Harbor

38 Hubbard, R., Brown, P.K. and Bownds, D. (1971) Methodology of vitamin A and visual pigments. Methods Enzymol. 5575, 615-653 CrossRef

39 Groenendijk, G.W.T., Jansen, P.A.A., Bonting, S.L. and Daemen, F.J.M. (1980) Analysis of geometrically isomeric vitamin A compounds. Methods Enzymol. 67, 203-220 CrossRef PubMed

40 Laemmli, U.K. (1970) Cleavage of structural proteins during the assembly of the head of bacteriophage T4. Nature 227, 680-685 CrossRef PubMed

41 Gordeliy, V.I., Labahn, J., Moukhametzianov, R., Efremov, R., Granzin, J., Schlesinger, R., Büldt, G., Savopol, T., Scheidig, A.J., Klare, J.P. and Engelhard, M. (2002) Molecular basis of transmembrane signalling by sensory rhodopsin II-transducer complex. Nature 419, 484-487 CrossRef PubMed

42 Luecke, H., Schobert, B., Stagno, J., Imasheva, E.S., Wang, J.M., Balashov, S.P. and Lanyi, J.K. (2008) Crystallographic structure of xanthorhodopsin, the light-driven proton pump with a dual chromophore. Proc. Natl. Acad. Sci. U.S.A. 105, 16561-16565 CrossRef PubMed

43 Vriend, G. (1990) WHAT IF: a molecular modeling and drug design program. J. Mol. Graph. 8, 52-56 CrossRef PubMed

44 Krieger, E., Koraimann, G. and Vriend, G. (2002) Increasing the precision of comparative models with YASARA NOVA: a self-parameterizing force field. Proteins 47, 393-402 CrossRef PubMed

45 Xiao, Y., Partha, R., Krebs, R. and Braiman, M. (2005) Time-resolved FTIR spectroscopy of the photointermediates involved in fast transient $\mathrm{H}^{+}$release by proteorhodopsin. $\mathrm{J}$. Phys. Chem. B 109, 634-641 CrossRef PubMed

46 Brown, L.S. and Jung, K.H. (2006) Bacteriorhodopsin-like proteins of eubacteria and fungi: the extent of conservation of the haloarchaeal proton-pumping mechanism. Photochem. Photobiol. Sci. 5, 538-546 CrossRef PubMed

47 Yong, J.Y., Reum, A.R., Kyung, Y.K., Kum, H.K. and Jung, K.H. (2008) Spectroscopic and photochemical analysis of proteorhodopsin variants from the surface of the Arctic Ocean. FEBS Lett. 582, 1679-1684 CrossRef PubMed

48 Dioumaev, A.K., Wang, J.M., Bálint, Z., Váró, G. and Lanyi, J.K. (2003) Proton transport by proteorhodopsin requires that the retinal Schiff base counterion Asp-97 be anionic. Biochemistry 42, 6582-6587 CrossRef PubMed

49 Choi, A.R., Shi, L., Brown, L.S. and Jung, K.H. (2014) Cyanobacterial light-driven proton pump, Gloeobacter rhodopsin : complementarity between rhodopsin-based energy production and photosynthesis. PLOS ONE $\mathbf{9}, 1-10$

50 Lee, K.A. and Jung, K.H. (2011) ATP regeneration system using E. coli ATP synthase and Gloeobacter rhodopsin and its stability. J. Nanosci. Nanotechnol. 11, 4261-4264 CrossRef PubMed

51 Reckel, S., Gottstein, D., Stehle, J., Löhr, F., Verhoefen, M.K., Takeda, M., Silvers, R., Kainosho, M., Glaubitz, C. Wachtveitl, J. et al. (2011) Solution NMR structure of proteorhodopsin. Angew. Chem. Int. Ed. Engl. 50, 11942-11946 CrossRef PubMed

52 Bamann, C., Bamberg, E., Wachtveitl, J. and Glaubitz, C. (2014) Proteorhodopsin. Biochim. Biophys. Acta 1837, 614-625 CrossRef PubMed

53 Rupenyan, A., van Stokkum, I.H.M., Arents, J.C., van Grondelle, R., Hellingwerf, K. and Groot, M.L. (2008) Characterization of the primary photochemistry of proteorhodopsin with femtosecond spectroscopy. Biophys. J. 94, 4020-4030 CrossRef PubMed

54 Malmerberg, E., Omran, Z., Hub, J.S., Li, X., Katona, G., Westenhoff, S., Johansson, L.C., Andersson, M., Cammarata, M., Wulff, M. et al. (2011) Time-resolved WAXS reveals accelerated conformational changes in iodoretinal-substituted proteorhodopsin. Biophys. J. 101, 1345-1353 CrossRef PubMed

55 Wald, G. (1968) The molecular basis of visual excitation. Nature 219, 800-807 CrossRef PubMed

56 Harbison, G.S., Smith, S.O., Pardoen, J.A., Courtin, J.M.L., Lugtenburg, J., Herzfeld, J., Mathies, R.A. and Griffin, R.G. (1985) Solid-state ${ }^{13} \mathrm{C}$ NMR detection of a perturbed 6-s-trans chromophore in bacteriorhodopsin. Biochemistry 24, 6955-6962 CrossRef PubMed 
57 Sheves, M., Friedman, N., Rosenbach, V. and Ottolenghi, M. (1984) Preparation of (1,1,5-tri-demetyl) bacteriorhodopsin pigment and its photocycle study. FEBS Lett. 166, 245-247 CrossRef

58 Imasheva, E.S., Balashov, S.P., Choi, A.R., Jung, K.H. and Lanyi, J.K. (2009) Reconstitution of Gloeobacter violaceus rhodopsin with a light-harvesting carotenoid. Biochemistry 48, 10948-10955 CrossRef PubMed

59 Balashov, S.P., Imasheva, E.S., Choi, A.R., Jung, K.H., Liaaen-Jensen, S. and Lanyi, J.K. (2010) Reconstitution of Gloeobacter rhodopsin with echinenone: role of the 4-keto group. Biochemistry 49, 9792-9799 CrossRef PubMed

60 Balashov, S.P., Imasheva, E.S., Boichenko, V.A., Antón, J., Wang, J.M. and Lanyi, J.K. (2005) Xanthorhodopsin: a proton pump with a light-harvesting carotenoid antenna. Science 309, 2061-2064 CrossRef PubMed

Received 30 September 2014/27 January 2015; accepted 6 February 2015

Published as BJ Immediate Publication 6 February 2015, doi:10.1042/BJ20141210
61 Imasheva, E.S., Balashov, S.P., Wang, J.M., Smolensky, E., Sheves, M. and Lanyi, J.K. (2008) Chromophore interaction in xanthorhodopsin: retinal dependence of salinixanthin binding. Photochem. Photobiol. 84, 977-984 CrossRef PubMed

62 Chow, B.Y., Han, X., Dobry, A.S., Qian, X., Chuong, A.S., Li, M., Henninger, M.A., Belfort, G.M., Lin, Y., Monahan, P.E. and Boyden, E.S. (2010) High-performance genetically targetable optical neural silencing by light-driven proton pumps. Nature $\mathbf{4 6 3}, 98-102$ CrossRef PubMed

63 Deisseroth, K. (2010) Controlling the brain with light. Sci. Am. 303, 48-55 CrossRef PubMed

64 Kralj, J.M., Hochbaum, D., Douglass, A. and Cohen, A. (2011) Electrical spiking in Escherichia coli. Science 333, 345-348 CrossRef PubMed 